\title{
Themen und Fragen der UNCED
}

Origines, thèmes et enjeux de la CNUED

Andràs November, Jacques Grinevald, Pierre Portas et Christophe Dunand

\section{OpenEdition}

\section{Journals}

Édition électronique

URL : http://journals.openedition.org/sjep/1388

DOI : 10.4000/sjep.1388

ISSN : 1663-9677

\section{Éditeur}

Institut de hautes études internationales et du développement

\section{Édition imprimée}

Date de publication : 1 janvier 1992

Pagination : 159-175

ISSN : 1660-5926

Référence électronique

Andràs November, Jacques Grinevald, Pierre Portas et Christophe Dunand, «Themen und Fragen der UNCED », Schweizerisches Jahrbuch für Entwicklungspolitik [En ligne], 11 | 1992, mis en ligne le 19 mai 2013, consulté le 08 septembre 2020. URL : http://journals.openedition.org/sjep/1388 ; DOI : https:// doi.org/10.4000/sjep.1388

Ce document a été généré automatiquement le 8 septembre 2020

(c) The Graduate Institute 


\section{Themen und Fragen der UNCED}

Origines, thèmes et enjeux de la CNUED

Andràs November, Jacques Grinevald, Pierre Portas et Christophe Dunand

NOTE DE L'ÉDITEUR

Volltext auf Französisch in Annuaire suisse de politique de développement: „Origines, thèmes et enjeux de la CNUED", http://aspd.revues.org/1561. 